\title{
Environmental factors and chemical agents affecting the growth of the pathogenic marine ciliate Uronema nigricans
}

\author{
P. B. B. Crosbie*, B. L. Munday \\ School of Aquaculture, University of Tasmania, PO Box 1214, Launceston 7250, Tasmania, Australia
}

\begin{abstract}
The scuticociliate Uronema nigricans is an opportunistically parasitic marine ciliate known to cause disease in some aquacultural environments with epizootics documented from marine larval rearing systems, marine aquaria and in southern bluefin tuna Thunnus macoyii growout enclosures. This study examined growth responses of laboratory cultures of the ciliate and prey bacteria to variations in temperature and salinity, and the efficacy of potential chemotherapeutants for control of $U$. nigricans infections. Differences in ciliate growth responses were marginal at temperatures of 10 to $25^{\circ} \mathrm{C}$ and at salinities between 15 and $35 \mathrm{ppt}$, though $3.5 \mathrm{ppt}$ or less was lethal. Ciliates were found to be sensitive to fluctuations in bacterial densities, which may be a factor in the seasonal occurrence of the ciliate-related disease in tuna. Commonly used chemotherapeutants such as formalin, malachite green and hydrogen peroxide were all effective against the ciliate during in vitro trials
\end{abstract}

KEY WORDS: Uronema nigricans - Opportunistic pathogen - Growth response - Chemotherapeutants

\section{INTRODUCTION}

Until recently, infections of fish with Uronema sp. (Order: Scuticociliatida) had been mainly reported in aquarium species in which they were invasive and resulted in severe tissue damage and subsequent mortalities (Cheung et al. 1980, Bassleer 1983). More recently the potential for scuticociliatids to be a problem in mariculture has been highlighted by reports of serious disease of larval and juvenile fish in Japan and Spain attributed to infection with Uronema sp. (Yoshinaga \& Nakazoe 1993, Dykova \& Figueras 1994) and, of mature sea bass in the Mediterranean, where the parasite was described as Philasterides dicentrarchi (Dragesco et al. 1995). In Australia mortalities of southern bluefin tuna Thunnus maccoyii in growout seacages have also been reported with the causative agent being identified as Uronema nigricans (Munday et al. 1997).

This paper consists of 2 parts. The first reports the in vitro growth responses of Uronema nigricans to variations in temperature and salinity which were investi-

•E-mail: philip.crosbie@utas.edu.au gated to gather fundamental information on environmental parameters influencing growth of this ciliate. The second provides information on potential chemotherapeutants for the control of $U$. nigricans infections of fish in closed larvae-rearing systems and aquaria.

\section{MATERIALS AND METHODS}

Stock cultures of ciliates and bacteria. Stock cultures of Uronema nigricans were laboratory cultures held by the School of Aquaculture, University of Tasmania, and were originally isolated from infected tuna tissue (Munday et al. 1997). These cultures were grown with a variety of marine bacteria as a food source.

Cultures of Vibrio anguillarum for use as one of the bacterial food sources for the ciliates were obtained from the microbiology laboratory within the Department of Applied Biomedical Science, University of Tasmania.

Maintenance of ciliate cultures. Ciliates were cloned using the silicon oil plate procedure detailed by Soldo \& Brickson (1993) and were maintained and sub- 
cultured every 5 to $6 \mathrm{wk}$ by procedures described by Watts (1995). Briefly, culture vessels were $25 \mathrm{ml}$ McCartney bottles containing a 1 in 10 dilution of brain heart infusion (Oxoid ${ }^{\circledR}$ ) broth supplemented with $25 \mu \mathrm{l}$ $\mathrm{l}^{-1}$ of both defibrinated horse blood and multi vitamin supplement (Accomin ${ }^{3}$ ). The bacterial load of 1 isolate was suppressed by a process involving the use of antibiotics, repeated centrifugation and exploitation of the ciliates' geotactic nature, then maintained at room temperature in a marine axenic medium (MAM) as modified from Messick \& Small (1996).

Growth rate estimations of ciliates and bacteria. Ciliate growth rates were measured in response to variations in temperature $\left(10,15,20,25\right.$ and $\left.30^{\circ} \mathrm{C}\right)$ or salinity $\left(0,15,25\right.$ and 35 ppt, all incubated at $\left.20^{\circ} \mathrm{C}\right)$ in quadruplicate batch cultures. Cultures were performed in $25 \mathrm{ml} \mathrm{McCartney} \mathrm{bottles} \mathrm{containing} 20 \mathrm{ml}$ of $0.2 \mu \mathrm{m}$ filtered seawater, $2 \mathrm{ml} 1 \%$ peptone and $1 \mathrm{ml}$ Vibrio anguillarum suspended in $1 \%$ peptone (for an initial density of $10^{8}$ cells $\mathrm{ml}^{-1}$ ). Growth trials were initiated by an inoculation with a ciliate suspension drawn from stock cultures in exponential growth phase (subcultured from MAM broth to $1 \%$ peptone seeded with $V$. anguillarum approximately $48 \mathrm{~h}$ prior to initiation of the experiment) to give an initial density of approximately 100 to 200 ciliates $\mathrm{ml}^{-1}$. At appropriate time intervals (approximately every 10 to $14 \mathrm{~h}$ over 7 d) all cultures were sampled to enumerate ciliates. For counting, $0.5 \mathrm{ml}$ samples were taken from thoroughly mixed suspensions and fixed with $0.5 \mathrm{ml}$ of $10 \%$ formalin. Densities were estimated as the average of quadruplicate counts of ciliates in $20 \mu \mathrm{l}$ sub-samples in a Sedgewick-Rafter counting chamber. However, when ciliate densities were low, 50 to $200 \mu$ sub-samples were used. Culture volumes were never diminished by more than half in the course of sampling.

Optimal conditions for the ciliate in terms of temperature and salinity were determined from growth curves and, in particular, net ciliate production which was calculated by: $N-N_{0}$ where $N_{0}$ and $N$ are ciliate numbers at the beginning and end of exponential growth phase respectively.

To investigate ciliate tolerance to lower salinities between 3.5 and $10 \mathrm{ppt}$, culture methods based on those of Novotny et al. (1996) were used. Seven day old ciliate cultures were concentrated by centrifugation (3000 rpm, $500 \times \mathrm{g}$, for $5 \mathrm{~min}$ ) then re-suspended in filtered seawater. Effects of salinities 3.5, 5, 7.5 and 10 ppt were observed in individual wells of 6 -well tissue culture trays (Greiner Labortechnik ) when $200 \mu \mathrm{l}$ of ciliate culture was added to $1.8 \mathrm{ml}$ of appropriately diluted seawater. The procedure was performed twice to ensure that it was repeatable.

Bacteria were enumerated as colony-forming units (CFUs) on $1 \%$ peptone agar using the spread plate viable count method. Where morphologically different cells were present, indicating mixed bacterial populations, elementary identification methods (i.e. Gram stains and isolation onto thiosulphate citrate bile salt media) were used to determine whether or not that the organisms were Vibriosp

Determination of the efficacy of therapeutants. Methods used to appraise therapeutants were similar to those used to assess reduced salinity tolerance. The effects were observed using $1.8 \mathrm{ml}$ of ciliate suspension (centrifuged and re-suspended in $2 \mu \mathrm{m}$ filtered seawater as before) with $200 \mu$ l of suitably diluted therapeutants to give the desired final concentration. Ciliate densities for each trial ranged from $1.7 \times 10^{4}$ to $4.4 \times 10^{4}$ cells $\mathrm{ml}^{-1}$. Compounds tested for efficacy in killing the ciliates were formalin $(25,50,100,200 \mathrm{ppm})$, malachite green $(1,2,4,6,8$ ppm) and hydrogen peroxide $(250,500,1000,1500,2000 \mathrm{ppm})$. All trials were performed in triplicate wells for each compound and concentration and with appropriate controls ( $200 \mu \mathrm{l}$ of seawater in lieu of therapeutants). Effects of therapeutants on motility and morphology were observed periodically by scanning several fields of view at 100 and $200 \times$ magnification using an inverted microscope (Zeiss ${ }^{(3)}$ Invertoscope ID 02) and assigning scores, interpretations of which are outlined in Table 1. Assay temperatures ranged from 18 to $20^{\circ} \mathrm{C}$ and maximum period for observation was set at $180 \mathrm{~min}$.

Statistical analysis. Cell density data were analysed with a 1 -way analysis of variance (ANOVA). Significant differences were highlighted as a multiple com-

Table 1 Scoring system for appraising the effects of various compounds on motility and morphology of Uronema sp. (Modified from Novotny et al. 1996)

\begin{tabular}{|c|c|}
\hline Score & Interpretation \\
\hline \multicolumn{2}{|c|}{ Motility } \\
\hline 4 & No effect; motility normal \\
\hline 3 & Motility slowed in more than $50 \%$ of ciliates \\
\hline 2 & $\begin{array}{l}\text { Approximately } 50 \% \text { of ciliates stationary, but } \\
\text { cilia still beating }\end{array}$ \\
\hline 1 & $\begin{array}{l}\text { More than } 50 \% \text { of ciliates stationary and cilia } \\
\text { still beating }\end{array}$ \\
\hline 0 & No sign of motility or cilia movement \\
\hline \multicolumn{2}{|c|}{ Morphology } \\
\hline 4 & No change; cells elliptical \\
\hline 3 & $\begin{array}{l}\text { Less than } 50 \% \text { of cells round or irregular } \\
\text { shape }\end{array}$ \\
\hline 2 & $\begin{array}{l}\text { Approximately } 50 \% \text { of cells round or irregular } \\
\text { shape }\end{array}$ \\
\hline 1 & $\begin{array}{l}\text { More than } 50 \% \text { of cells round or irregular and } \\
\text { lysis evident }\end{array}$ \\
\hline 0 & Extensive lysis with few cells intact \\
\hline
\end{tabular}


parisons of means (Tukey-Kramer HSD test) was carried out. For all tests a significance level of $p<0.05$ was adopted.

\section{RESULTS}

\section{Growth trials at varying temperature and salinity}

There appeared a general trend in all Uronema nigricans growth curves of a slowing of growth at the end of exponential growth phase, followed by a decline, then an increase. Growth curves for ciliates and bacteria (Fig. 1) at 10 and $30^{\circ} \mathrm{C}$ only are presented here as these are representative of the data at all incubation temperatures. There was no indication of a final death phase at any of the incubation temperatures over a period of $185 \mathrm{~h}$. The data generally show typical predator-prey oscillations in bacterial and ciliate populations. However, at 10 and $15^{\circ} \mathrm{C}$ there was a sharp decline in bacterial numbers after $25 \mathrm{~h}$ which did not quite coincide with the initial surge in ciliate numbers.
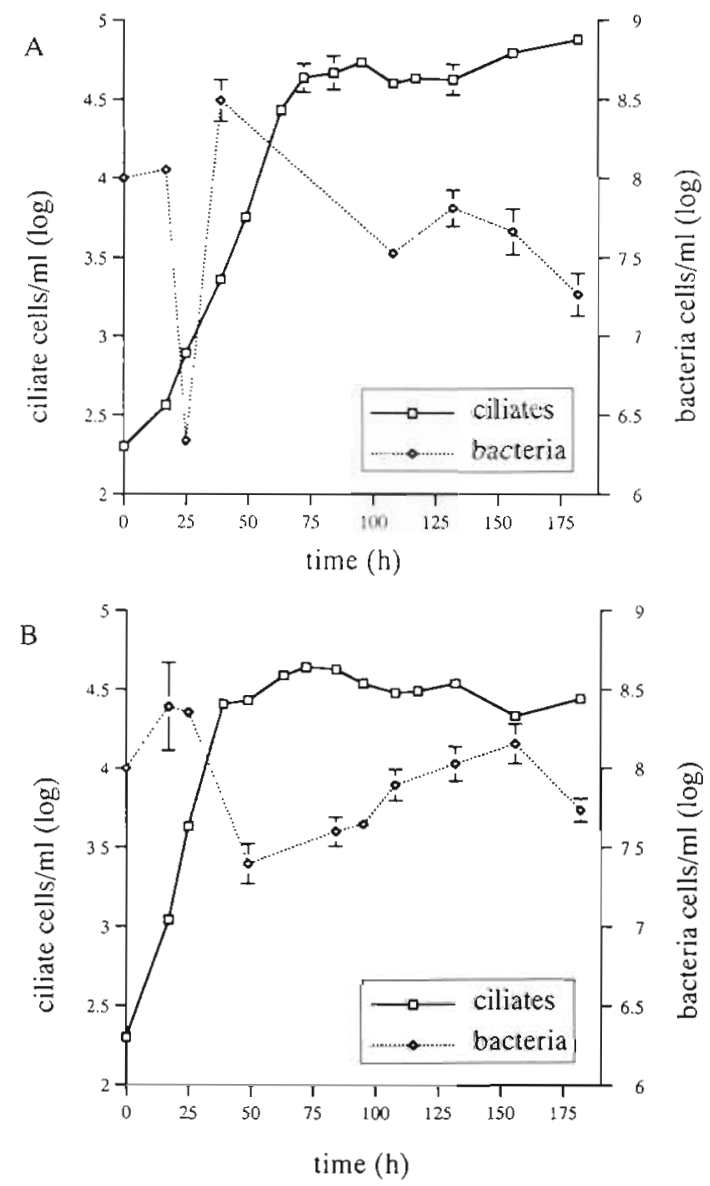

Fig. 1. Growth curves for the ciliate and bacteria incubated at (A) $10^{\circ} \mathrm{C}$ and (B) $30^{\circ} \mathrm{C}$. All values are means $\pm \mathrm{SE}$ ( $\mathrm{n}=4$ except for some bacteria counts where $n=2$ or 3 )
Table 2. Uronema nigricans. Maximum cell densities achieved during exponential phase and for the duration of the growth trial (185 h) where ciliates were cultured at a range of salinithes. All values are means $\pm S E(n=4)$ and those sharing a common superscript are not significantly different $(p>0.05$. Tukey-Kramer HSD test)

\begin{tabular}{|lcc|}
\hline $\begin{array}{l}\text { Temperature } \\
\left({ }^{\circ} \mathrm{C}\right)\end{array}$ & \multicolumn{2}{c|}{$\begin{array}{c}\left.\text { Maximum densities } \times 10^{4} \text { (cells } \mathrm{ml}^{-1}\right) \\
\text { Exponential phase }\end{array}$} \\
\hline 10 & $5.138^{\mathrm{ab}} \pm 0.1093$ & $7.656^{\mathrm{a}} \pm 0.1663$ \\
15 & $5.081^{\mathrm{ab}} \pm 0.1634$ & $8.781^{\mathrm{a}} \pm 0.4641$ \\
20 & $5.863^{\mathrm{a}} \pm 0.7631$ & $8.700^{\mathrm{a}} \pm 0.2963$ \\
25 & $4.688^{\mathrm{ab}} \pm 0.5447$ & $7.275^{\mathrm{ab}} \pm 0.4147$ \\
30 & $2.731^{\mathrm{b}} \pm 0.1637$ & $4.788^{\mathrm{b}} \pm 0.4421$ \\
\hline
\end{tabular}

Table 3. Uronema nigricans. Maximum cell densities achieved during exponential phase and for the duration of the growth trial (185 h) where ciliates were cultured at a range of salinities and at $20^{\circ} \mathrm{C}$. All values are means $\pm \mathrm{SE}(\mathrm{n}=4)$ and those sharing a common superscript are not significantly different ( $p>0.05$, Tukey-Kramer HSD test)

\begin{tabular}{|c|c|c|}
\hline \multirow[t]{2}{*}{ Salinity (ppt) } & \multicolumn{2}{|c|}{ Maximum densities $\times 10^{4}$ (cells $\left.\mathrm{ml}^{-1}\right)$} \\
\hline & Exponential phase & Duration of trial \\
\hline 15 & $4.475^{a} \pm 0.211$ & $6.838^{a} \pm 0.419$ \\
\hline 25 & $4.288^{\circ} \pm 0.372$ & $7.288^{\prime 1} \pm 0.225$ \\
\hline 35 & $5.863^{a} \pm 0.763$ & $8.700^{b} \pm 0.296$ \\
\hline
\end{tabular}

Maximum ciliate densities achieved during exponential growth phase and for the duration of the trial (Table 2) were significantly lower at $30^{\circ} \mathrm{C}$.

Attempts to culture Uronema nigricans in freshwater failed as cells immediately swelled and lysed. However, there was little difference in growth curves at salinities of 15,25 and 30 ppt (Fig. 2, Table 3) with the exception being that the maximum yield over the

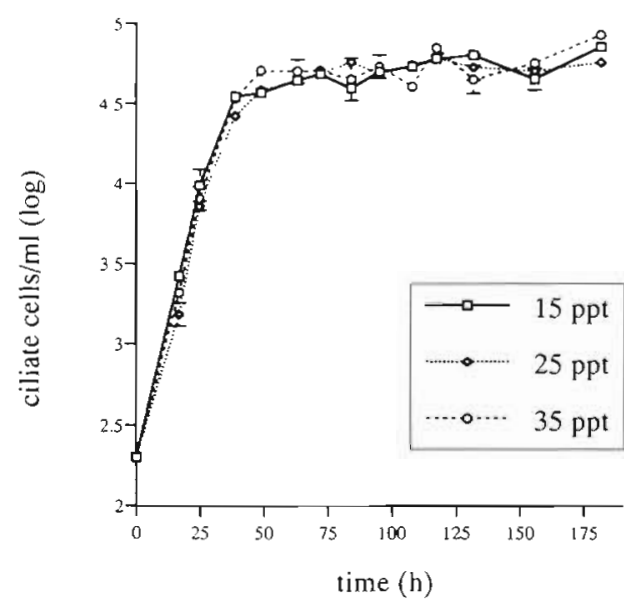

Fig. 2. Uronema nigricans. Growth curves forciliates incubated at $20^{\circ} \mathrm{C}$ and cultured in a range of salinities. All values are means $\pm \operatorname{SE}(n=4)$ 
course of the trial was significantly higher in fullstrength seawater. It was also found that salinities of $3.5 \mathrm{ppt}$ or less are lethal to $U$. nigricans but there was significant ciliate survival at salinities higher than these (data not presented), with no impact observed at $10 \mathrm{ppt}$.

Two morphologically distinct groups of bacteria were present on some plates up to approximately $66 \mathrm{~h}$ post incubation. Both were regarded as Vibrio spp. as they grew on TCBS plates within $24 \mathrm{~h}$. Towards the end of the trial period different bacteria were evident as red, translucent colonies (Gram negative and no growth on TCBS). However, these were a relatively small proportion of the total bacterial population.

\section{Effects of therapeutants}

All the therapeutants tested were lethal to the ciliates with responses characterised by changes in motility and morphology. Changes in motility were reasonably constant for each compound; cells would slow down, become stationary and cilia would cease beating. The ciliates were assumed to be dead at this point.

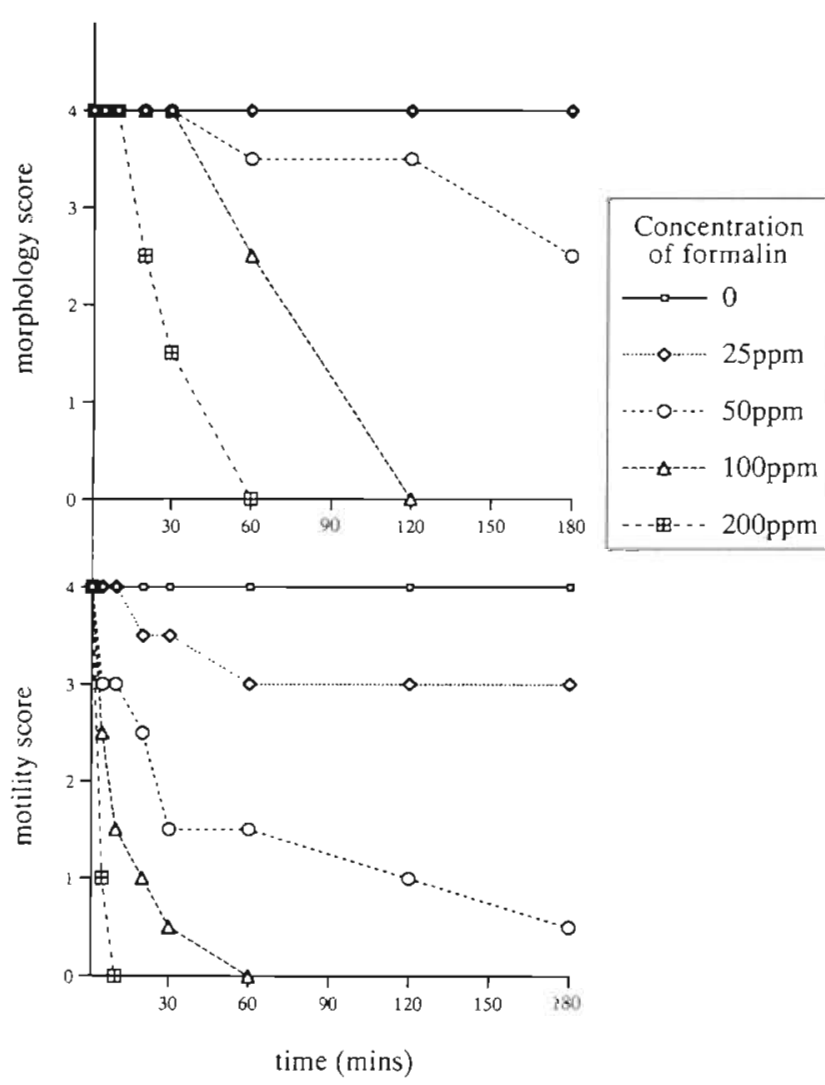

Fig. 3. Uronema nigricans. Observed effects of a range of concentrations of formalin on morphology and motility. Each data point represents the mean of 2 replicate experiments
Effects on cell morphology were more varied. Prior to treatment the protozoans were ovoid in shape. Organisms exposed to hydrogen peroxide developed bulging of the cytoplasm through the oral cavity before swelling to a round or irregular shape and lysing. Formalin and malachite green induced cell rounding prior to eventual lysis. Assigned scores for all compounds at the various concentrations appear in Figs. 3,4 \& 5 .

The most effective concentrations of formalin were 100 and 200 ppm where total cell lysis occurred after 120 and $60 \mathrm{~min}$ respectively. At these concentrations the ovoid cell shape was maintained for 20 to $40 \mathrm{~min}$ after motility had ceased in the majority of cells. Lower concentrations of formalin did not result in $100 \%$ mortality, with no real effect noted at $25 \mathrm{ppm}$, and the response to $50 \mathrm{ppm}$ varied slightly between trials but indicated significant ciliate survival after 180 min. Hydrogen peroxide was lethal to the ciliate at all concentrations. There was slight variation in cell response between each concentration $30 \mathrm{~min}$ after treatment, but mortality was complete for all after $60 \mathrm{~min}$. With this compound morphological changes occurred within $10 \mathrm{~min}$ of cessation of motility in the majority of cells. Malachite green was also lethal at each concentration

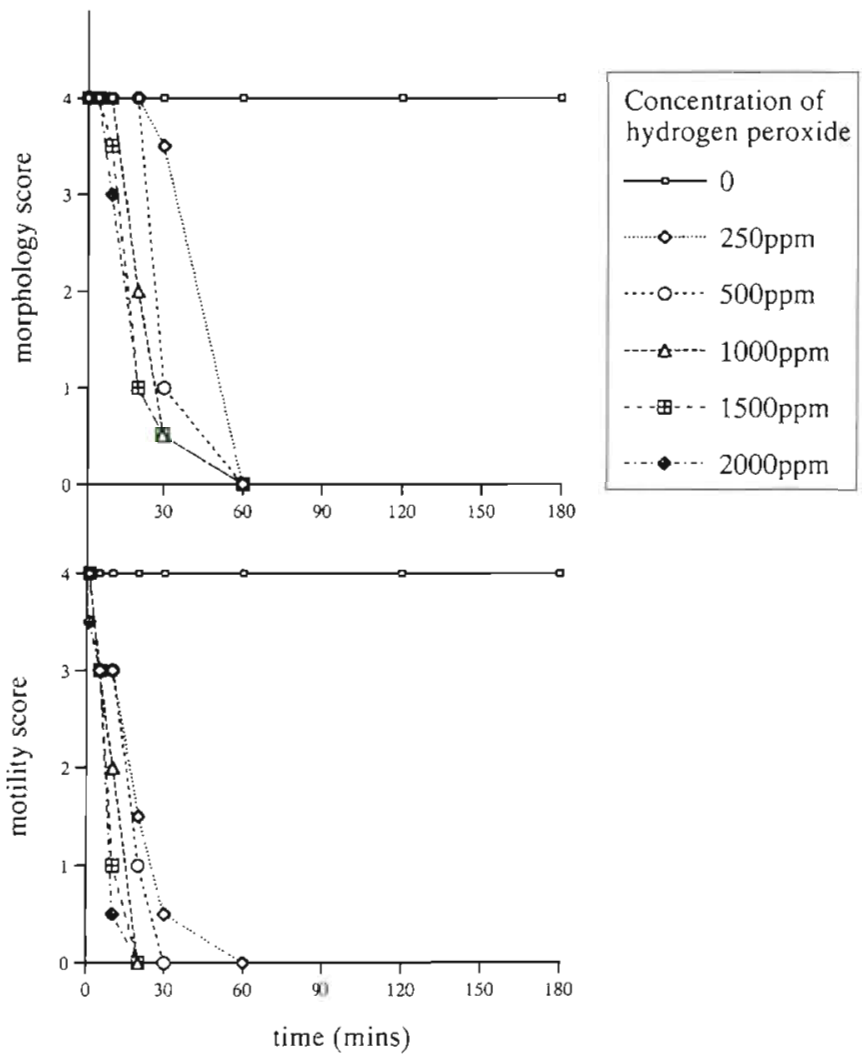

Fig. 4. Uronema nigricans. Observed effects of a range of concentrations of hydrogen peroxide on morphology and motility. Each data point represents the mean of 2 replicate experiments 


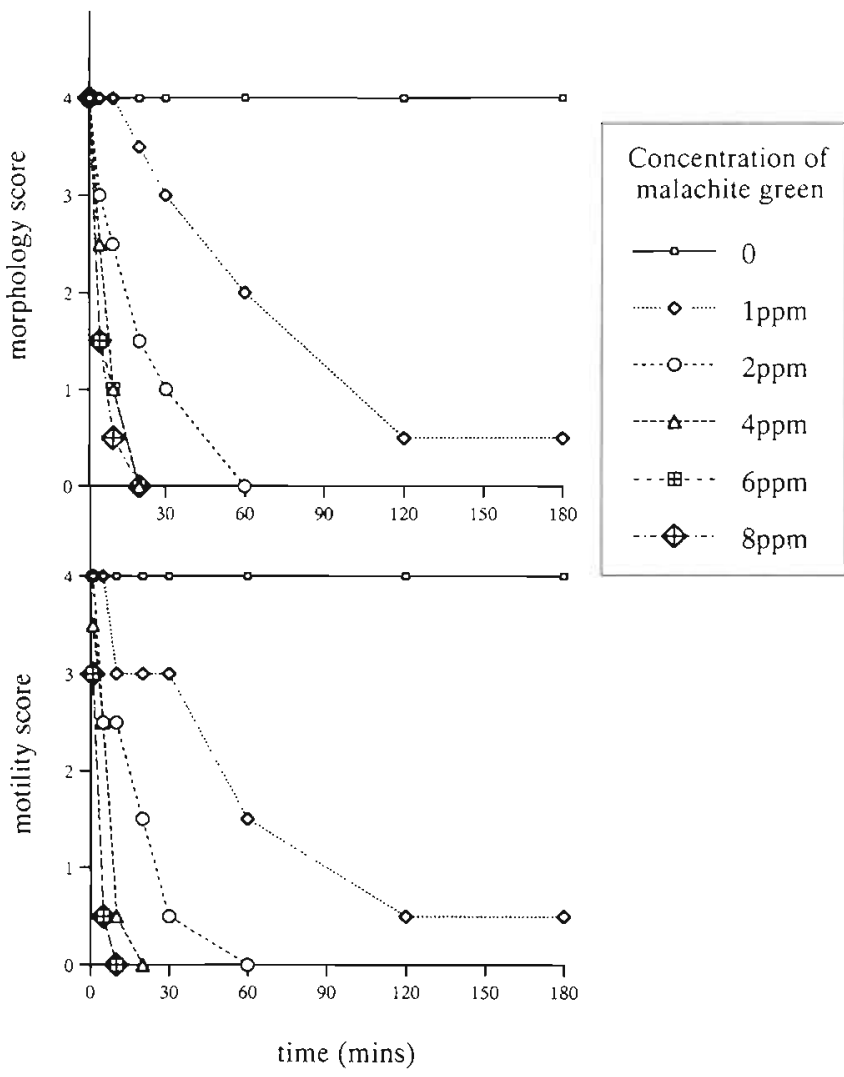

Fig. 5. Uronema nigricans. Observed effects of a range of concentrations of malachite green on morphology and motility. Each data point represents the mean of 2 replicate experiments

used although there was some variation at $1 \mathrm{ppm}$ with cells surviving after $180 \mathrm{~min}$ for 1 trial. Higher concentrations, i.e. 4, 6 and $8 \mathrm{ppm}$, all resulted in total mortality within $20 \mathrm{~min}$.

\section{DISCUSSION}

It is notable that the maximum ciliate densities achieved during exponential phase and for the duration of the observations varied little with temperature although the highest concentrations tended to be at 2.5 and $30^{\circ} \mathrm{C}$. This suggests that ciliates can grow and be maintained across a wide temperature range (in the order of 10 to $25^{\circ} \mathrm{C}$ ).

Generally, growth curves for both ciliates and bacteria illustrated typical predator-prey relationships though at 10 and $15^{\circ} \mathrm{C}$ there were 2 distinct troughs in the growth curves for bacteria. These troughs occurred before the ciliates entered exponential phase and thus appeared due to a temperature effect on the bacteria rather than a grazing effect by the ciliates. Bacterial numbers recovered over the next $14 \mathrm{~h}$, suggesting a change in species of the dominant bacteria. For this experiment it was possible that changes in proportions of different bacterial species may have introduced another variable which may bave influenced the results. However, as one of the aims of this experiment was to identify the ranges of temperatures and salinities in nature under which the ciliates thrive, and the possible effects of total bacterial load on growth, we believe that our system reflected the situation likely to be encountered in aquaculture settings

A direct temperature effect on the ciliates may be marginal as the probable permissive temperatures established by this study are in the range of 10 to $25^{\circ} \mathrm{C}$. It is probably pertinent that ciliate densities are very sensitive to changes in bacterial densities. Thus, variations in total bacterial load or, in proportions of different bacteria, due to a change in temperature would logically impact on the ciliate population by affecting their food supply. Even though Uronema spp. are bacterivorous, they are also opportunistic pathogens and may become histophagous (Lom \& Dykova 1992). Changes in bacterial diversity or load in cooler temperatures may represent a scarcity of food for the ciliates and result in the typical ciliate response to starvation, which is rapid cell division with a subsequent decrease in cell volume, rapid motility and swarming behaviour (Fenchel 1990). Thus, in the absence of sufficient bacteria, tuna may be preferentially colonised during the colder months of the year (water temperatures less than $18^{\circ} \mathrm{C}$ ), especially as their internal body temperature will be above ambient (Brill et al. 1994) and they may be immuno-compromised by confinement and possible nutritional deficiencies as noted by Munday et al. (1997).

Growth responses of Uronema nigricans to salinities of 15 and 25 ppt did not vary from those in full-strength seawater. Hamilton \& Preslan (1969) noted the same lack of variation in growth rates of a Uronema sp. at salinities of 17 and 43 ppt. Similarly, Cheung et al. (1980) noted a wide range of both salinity (20 to $31 \mathrm{ppt}$ ) and temperature $\left(8\right.$ to $\left.28^{\circ} \mathrm{C}\right)$ during an epizootic attributed to Uronema marinum at the New York aquarium. Although $U$. nigricans is vulnerable to salinities lower than $3.5 \mathrm{ppt}$, the use of freshwater or low salinity baths, from a surface disinfection perspective, are probably impracticable for controlling $U$. nigricans epizootics in ornamental aquaria, especially as significant ciliate survival was noted at 5 ppt and freshwater treatment would be detrimental to fish once the ciliate has invaded and damaged tissue (Bassleer 1983).

In the second part of the experiment all 3 potential therapeutants investigated proved lethal to the ciliates. Generally, effectiveness was determined by concentration but hydrogen peroxide was an exception with all concentrations trialed taking the same time to pro- 
duce end-point. This was also found for malachite green at concentrations above $4 \mathrm{ppm}$. Formalin was most effective at concentrations of 100 to $200 \mathrm{ppm}$, which concurs with effective concentrations identified by Novotny et al. (1996) during in vitro trials on the ciliate Anophryoides haemophila, a pathogen of the American lobster. This chemical is widely used in aquaculture as a fungicide and parasiticide, typically at 25 to $50 \mathrm{ppm}$ for extended periods (Tonguthai \& Chanratchakool 1992) and, at 167 to $250 \mathrm{ppm}$ for 60 min baths (Poupard 1978). In our studies lower concentrations (25 to $50 \mathrm{ppm}$ ) had no perceptible effect on the ciliates.

All concentrations of malachite green were effective against the ciliate, with total mortality recorded in virtually every case. This chemical is also widely used in aquaculture, principally as a fungicide for incubating fish eggs, but also as a treatment against ectoparasites on fish (Gerundo et al. 1991). Typical applications are as a 1 min immersion at $67 \mathrm{ppm}$ or as a bath/flush treatment at 1 to 2 ppm for 60 min (Poupard 1978). A synergistic effect of combinations of formalin and malachite green as demonstrated by Gilbert et al. (1979) on the ciliate Tetrahymena pyriformis was not investigated here but would be worth future study. Hydrogen peroxide also was effective against the ciliate, with total mortality observed within $60 \mathrm{~min}$ at concentrations 250 to $2000 \mathrm{ppm}$. However, this compound causes mortality in salmon at concentrations of 200 to $300 \mathrm{ppm}$ at $17^{\circ} \mathrm{C}$ for an exposure time of $2 \mathrm{~h}$ (Cameron 1994) and therefore may be of limited applicability. At concentrations of $100 \mathrm{ppm}$ for $3 \mathrm{~h}$ and $300 \mathrm{ppm}$ for $30 \mathrm{~min}$ at $15^{\circ} \mathrm{C}$ salmon survival was not affected (Cameron 1994) but it is not known whether these concentration/time regimes will kill Uronema nigricans. However, since no difference was recorded in times taken to reach end-points for concentrations ranging from 250 to $2000 \mathrm{ppm}$, it is possible that lower concentrations would be effective, albeit over a longer period. In vivo efficacy of these chemicals in controlling $U$. nigricans infections can only be confirmed by trials on infected fish, although formalin at concentrations ranging from 75 to 200 ppm has been used successfully to treat Uronema sp. infestations of seahorses at a commercial facility (N. Forteath pers. comm.).

The effect of the various compounds tested on ciliate morphology was varied and presumably relates to the killing mechanisms of the chemicals, but was more consistent on motility. Uronema nigricans is highly motile both at $4^{\circ} \mathrm{C}$ (culture storage temperatures) and at 18 to $20^{\circ} \mathrm{C}$ (temperatures at which trials were carried out) and a slowing in motility was the first noticeable effect. Similar observations were recorded by Novotny et al. (1996) in trials on the ciliate Anophryoides haemophila.
These experiments give useful preliminary results which will aid future investigations into both the ecology of Uronema nigricans and to treatment options to control infections in enclosed aquaculture systems.

Acknowledgements. Dr Tiina Hawkesford assisted in ciliate culture and suppression of bacterial load for one isolate. Ms Marianne Watts maintained and supplied original ciliate isolates and advised on the culture techniques.

\section{LITERATURE CITED}

Bassleer G (1983) Uronema marinum, a new and common parasite on tropical saltwater fishes. Freshw Mar Aquarium 6:78-81

Brill RW, Dewar H, Graham JB (1994) Basic concepts relevant to heat transfer in fishes, and their use in measuring the physiological thermoregulatory abilities of tunas. Environ Biol Fishes 40:109-124

Cameron DE (1994) AGD Field Research 1993/94. lll. Field testing of hydrogen peroxide with AGD-infected Atlantic salmon:-efficacy and toxicity. Reports from SALTAS 1993-94 Research and Development Programme, Hobart, p $119-125$

Cheung PJ, Nigrelli RF, Ruggieri GD (1980) Studies on the morphology of Uronema marinum Dujardin (Ciliatea: Uronematidae) with a description of the histopathology of the infection in marine fishes. J Fish Dis 3:295-303

Dragesco A, Dragesco J, Coste F, Gasc C, Romestand B, Raymond JC, Bouix G (1995) Philasterides dicentrarchi, n. sp.. (Ciliophora, Scuticociliatida), a histophagous opportunistic parasite of Dicentrarchus labrax (Linnaeus, 1758), a reared marine fish. Eur J Protistol 31:327-340

Dykova I, Figueras A (1994) Histopathological changes in turbot Scophthalmus maximus due to a histophagous ciliate. Dis Aquat Org 18:5-9

Fenchel T (1990) Adaptive significance of polymorphic life cycles in protozoa: responses to starvation and refeeding in two species of marine ciliates. J Exp Mar Biol. Ecol 136: $159-177$

Gerundo N, Alderman DJ, Clifton-Hadley RS, Feist SW (1991) Pathological effects of repeated doses of malachite green: a preliminary study. $J$ Fish Dis 14:521-532

Gilbert JP, Gratzket JB, Brown J (1.979) An in vitro method for testing synergistic action of parasiticides using malachite green and formalin as a model system. $J$ Fish Dis 2: $191-196$

Hamilton RD, Preslan JE (1969) Cultural characteristics of the pelagic marine hymenostome ciliate, Uronema sp. J Exp Mar Biol Ecol 4:90-99

Lom J, Dykova I (1992) Development in aquaculture and fisheries science, Vol 26. Protozoan parasites of fishes. Elsevier, Amsterdam, p 237-288

Messick GA, Small EB (1996) Mesanophrys chesapeakensis n. sp., a histophagous ciliate in the blue crab, Calinectes sapidus, and associated histopathology. Invertebr Biol 115 : $1-12$

Munday BL, O'Donoghue PJ, Rough K, Watts M, Hawkesford I (1997) Fatal encephalitis due to the scuticociliate Uronema nigncans (Mueller) in sea-caged, southern bluefin tuna, Thunnus maccoyii (Castelnau). Dis Aquat Org 30: $17-25$

Novotny MJ, Cawthorn RJ, Despres B (1996) In vitro effects of chemotherapeutants on the lobster parasite Anophryoides haemophila. Dis Aquat Org 24:233-237 
Poupard CJ (1978) Therapy of fish diseases. In: Roberts RJ (ed) Fish pathology. Bailliere Tindall, London, p 268-277

Soldo AT, Brickson SA (1993) Isolation, cloning, and axenic cultivation of marine ciliates. In: Kemp PF, Sherr BF. Sherr $E B$, Cole JJ (eds) Handbook of methods in aquatic microbial ecology. Lewis Publishers, Boca Raton, p 97-101

Tonguthai K, Chanratchakool P (1992) The use of chemotherapeutant agents in aquaculture in Thalland. In: Shariff $M$, Subasinghe RP, Arthur JR (eds) Diseases in Asian aquaculture. Fish Health Section, Asian Fisheries Society,

Editorial responsibility: Wolfgang Körting

Hannover, Germany
Manila, p 555-565

Watts M (1995) The development of a fluorescent antibody stain to identify a Uronema sp. (Ciliophora: Scuticocilitada) implicated in fatal encephalitis in farmed tuna (Thunnus maccoyii). Honours thesis, University of Tasmania, Launceston

Yoshinaga T. Nakazoe J (1993) Isolation and in vitro cultivation of an unidentified ciliate causing scuticociliatosis in Japanese flounder (Paralichthys olivaceus). Gyobyo Kenkyu 28:131-134

Submitted: November 23, 1998; Accepted: February 8, 1999 Proofs received from author(s): May 17, 1999 